\title{
Taxonomic status of Leptodactylus ochraceus, a forgotten species (Anura: Leptodactylidae)
}

\author{
Ulisses Caramaschi \\ Universidade Federal do Rio de Janeiro, Departamento de Vertebrados, Museu Nacional, Quinta da Boa Vista, \\ 20940-040 Rio de Janeiro, Rio de Janeiro, Brasil. E-mail: ulisses@acd.ufrj.br
}

\begin{abstract}
The taxonomic status of Leptodactylus ochraceus Lutz, 1930, a forgotten leptodactylid frog species, known only from the holotype, is reviewed. The holotype and the original color plate are described and the type locality is discussed and revised. The species is considered valid and distinct from all leptodactylids, leiuperids, cycloramphids, and ceratophrids occurring in Northeastern Brazil.

KEY WORDS. Amphibia; Bento Pickel; Tapera; Bonança; Pernambuco.
\end{abstract}

\begin{abstract}
RESUMO. A posição taxonômica de Leptodactylus ochraceus, uma espécie esquecida (Anura: Leptodactylidae). A posição taxonômica de Leptodactylus ochraceus Lutz, 1930, uma espécie de anfíbio leptodactilídeo esquecida, conhecida apenas do holótipo, é revisada. O holótipo e a prancha colorida original são descritos e a localidade tipo é discutida e atualizada. A espécie é considerada válida e distinta de todos os leptodactilídeos, leiuperídeos, cicloranfídeos e ceratofrídeos que ocorrem no Nordeste do Brasil.
\end{abstract}

PALAVRAS-CHAVE. Amphibia; Bento Pickel; Tapera; Bonança; Pernambuco.

Adolpho Lutz (1855-1940), one of the precursors and most distinguished Brazilian herpetologists, produced two major contributions to the knowledge of the genus Leptodactylus Fitzinger, 1826 (LuTz 1926, 1930), with a broad coverage of all known species and descriptions of several others. Among these, Leptodactylus ochraceus Lutz, 1930 was described on the basis of one specimen, "which seems to be an adult female" (LuTz 1930), from the State of Pernambuco, Brazil, collected by Dom Bento Pickel. The locality, "Tapera", was cited followed by a question mark ["Estado de Pernambuco (? Tapera)"]. There is a rather detailed description of the specimen, mainly based on color and external morphological characters. It mentions that "on opening the abdomen appear a few rather large creamcolored eggs". Together with the description, there are two pictures that make the new species "well shown in the colored figure".

The species was included as "Incertae Sedis" within Gastrotheca by Frost (2006) based on a personal communication from W. R. Heyer ["A Gastrotheca (Hylidae: Hemiphactinae)"], which led D. R. Frost to conclude that it is "presumably a junior synonym of Nototrema fissipes Boulenger, 1888 , on the basis of geography".

However, the examination of the holotype, the description, the original plate, and the figures presented by LuTz (1930) showed that the species clearly belongs to the genus Leptodactylus and not to Gastrotheca. The aim of this paper is to ascertain the taxonomic status of Leptodactylus ochraceus.

\section{MATERIAL AND METHODS}

The examined specimens are housed in the Museu Nacional, Rio de Janeiro, Brazil (MNRJ) and in the Adolpho Lutz Collection (AL-MN) deposited in MNRJ. The examined specimens are listed in the Appendix. Abbreviations of the measurements are: (SVL) snout-vent length, (HL) head length, (HW) head width, (IND) internarial distance, (END) eye to nostril distance, (ED) eye diameter, (UEW) upper eyelid width, (IOD) interorbital distance, (TD) tympanum diameter, (THL) thigh length, (TL) tibia length, (FL) foot length. Measurements were made with digital calipers and are expressed in millimeters (mm). Terminology follows HeYer et al. (1990).

\section{RESULTS}

\section{Leptodactylus ochraceus Lutz, 1930}

Holotype. AL-MN 1445, collected by Dom Bento Pickel, O.S.B. (Order of Saint Benedict), in December, 1927. Currently, the specimen is in poor condition, very damaged, with the fingers and toes lost, legs fragmented, right mandible broken, unhinged; belly totally opened, with internal organs exposed, including some eggs. Overall color faded, but a brown lateral stripe is visible from the posterior corner of eye, passing over the tympanum and ending on the middle of the flank.

Measurements of the holotype. SVL 41.7; HL 15.0; HW 14.8; IND 3.2; END 3.3; ED 4.5; IOD 3.8; TL 20.5. Measurements 
of UEW, TD, THL, and FL not possible due to the poor condition of the specimen. Eggs measured 2.2-2.3 $\mathrm{mm}$ in diameter.

Type locality and collector. The type locality of $L$. ochraceus was quoted as "Estado de Pernambuco (? Tapera)" in the original description, but abridged to "Tapera, Pernambuco" by BoKeRMANN (1966), as handwriten in the label of the holotype made by Bertha Lutz in 1968, when the Adolpho Lutz Collection was transferred to the MNRJ. Corrected to "Pernambuco (? Tapera)", as originally published, by Frost (2006). Tapera was an old station, established in 1888, in the railway called Estrada de Ferro Central de Pernambuco (see http://www.estacoesferroviarias.com.br/efcp_pe/tapera.htm; accessed on April 27, 2007). This locality is about $38 \mathrm{~km}$ distant from Recife, the capital of the State of Pernambuco, and belongs to the Municipality of Moreno ( $08^{\circ} 10^{\prime} \mathrm{S}, 35^{\circ} 05^{\prime} \mathrm{W}$, about $100 \mathrm{~m}$ altitude). In 1990, by an edict of the mayor of Moreno, the name of the district of Tapera was changed to Bonança.

Dom Bento Pickel, the collector of the holotype, was born on July 28, 1890 in the city of Markelsheim, southern Germany. His elementary and high-school education took place in his home town and after he immigrated to Brazil, landing in Recife on 14 November 1908. He made his religious profession in the Benedictine Order on January 15, 1910, in the Benedictine Monastery of Olinda, State of Pernambuco, Brazil, and received his sacerdotal ordination on February 2, 1915. He studied Philosophy and Theology in Olinda, concluding his studies in Rome, in 1913. He also studied Agronomy at the agricultural college maintained by the Benedictine Monastery in Olinda, but did not obtained that degree. He exercised his sacerdotal duties in Recife for several years and taught Languages in the Preparatory Course to the São Bento High School of Agriculture and Veterinary Medicine, in Olinda. From 1914 to 1936, he teached Botany, Phytopathology, and Entomology at the São Bento High School of Agriculture (Fig. 1), near the (at that time) Tapera Station, State of Pernambuco. As a distinguished botanist, in 1938 he came to the city of São Paulo, in the State of São Paulo, and worked in the Forest Hortus and in the Biological Institute. In 1960, he was compulsorily retired as Biologist of the Forestry Service of São Paulo. He died in São Paulo, on April 13, 1963. The herbarium of the Forest Institute of São Paulo (SPSF), created in 1896, received his name. Dom Bento Pickel maintained a friendly relationship with Adolpho Lutz and, during his time in Pernambuco, he sent several anuran specimens to him in Rio de Janeiro. For instance, LuTz (1930) described L. ochraceus based on the specimen received from Dom Bento Pickel, and described Hyla pickeli A. Lutz \& B. Lutz, 1938 (type-locality, Tapera, Pernambuco, Brazil) [currently Scinax pachycrus (Miranda-Ribeiro, 1937)] honoring him. On the basis of the facts presented above and the quotation "Estado de Pernambuco (? Tapera)" presented in LuTz (1930), the probability that the holotype of L. ochraceus came from that locality is very plausible.

Currently, the likely type locality of $L$. ochraceus has changed drastically. In 1967, the state government initiated the construc-

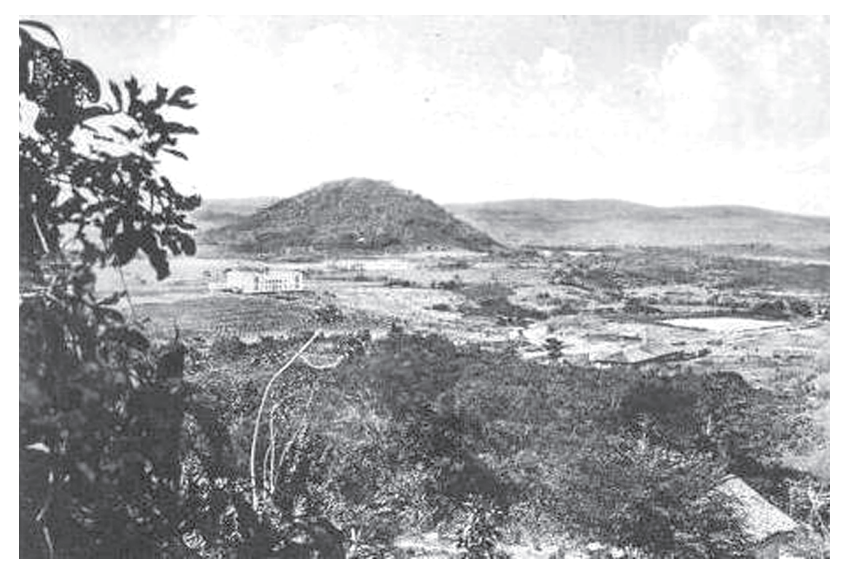

Figure 1. Escola Superior de Agricultura São Bento, Estação Tapera, Estrada de Ferro Central de Pernambuco, Brazil, beginning of the XX Century.

tion of a dam to supply potable water for the city of Recife. Despite strong opposition by the Benedictine monks, the São Bento High School was discontinued and closed in 1972, and in 1973 it was submerged by the flooding of the Tapacurá Dam. Nowadays, the old São Bento High School $\left(08^{\circ} 02^{\prime} 42.4^{\prime \prime}\right.$ S, 35 $\left.5^{\circ} 11^{\prime} 48.8^{\prime \prime} \mathrm{W}\right)$ is preserved as ruins in the middle of the dam (Figs 2-3).

Illustrations. The original plate of $L$. ochraceus is a typical drawing which Adolpho Lutz ordered from several painters under his orders. The plate is $85 \mathrm{~mm}$ wide and $122 \mathrm{~mm}$ high, on Schöler-type paper, currently with yellowish stains produced by oxydation. The numbers " 4 " and " $4 \mathrm{a}$ " near the figures and the signature "R. Honorio del." of the painter are visible, handwriten in weak pencil (Fig. 4). On the verse, it is handwriten in pencil, "Leptodactylus ochraceus Lutz / Pernambuco"; the cover paper indicates the same identification (Fig. 5).

The first figure (numbered " 4 ") shows the specimen in dorsal view, with semi-extended arms and legs (Fig. 6). Typically, the specimen was painted in watercolor, following strictly the original measurements and proportions. The second figure (numbered " $4 \mathrm{a}$ "), located imediately below the first one, shows a left lateral view of the specimen, from the snout to the middle of the body, and without the hand (Fig. 7).

Based on the figures, L. ochraceus would have the head wider than long; snout semi-circular in dorsal view, obtuse in profile; canthus rostralis marked, loreal region concave; eyes moderately salient; internarial distance, eye to nostril distance, and eye diameter approximately equal and slightly larger than the tympanum diameter and upper eyelid width, but smaller than the interorbital distance; tympanum approximately circular; thigh length slightly smaller than the tibia length, and both smaller than the foot length; sum of thigh and tibia lengths slightly larger than the snout-vent length; fingers and toes long, slender, without apical disks nor webbing.

Measurements of the figures: SVL 39; HL 12; HW 14; IND 


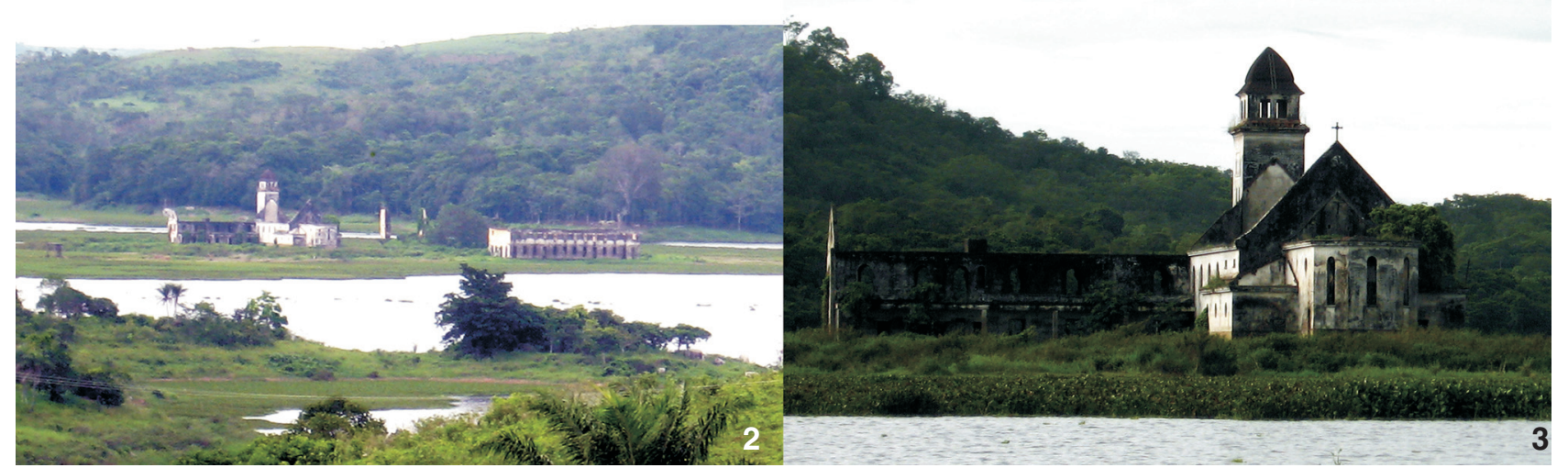

Figures 2-3. Ruins of the Escola Superior de Agricultura São Bento: (2) general view; (3) church and school annexes. Photographs made by U. Caramaschi on 31.III.2008.

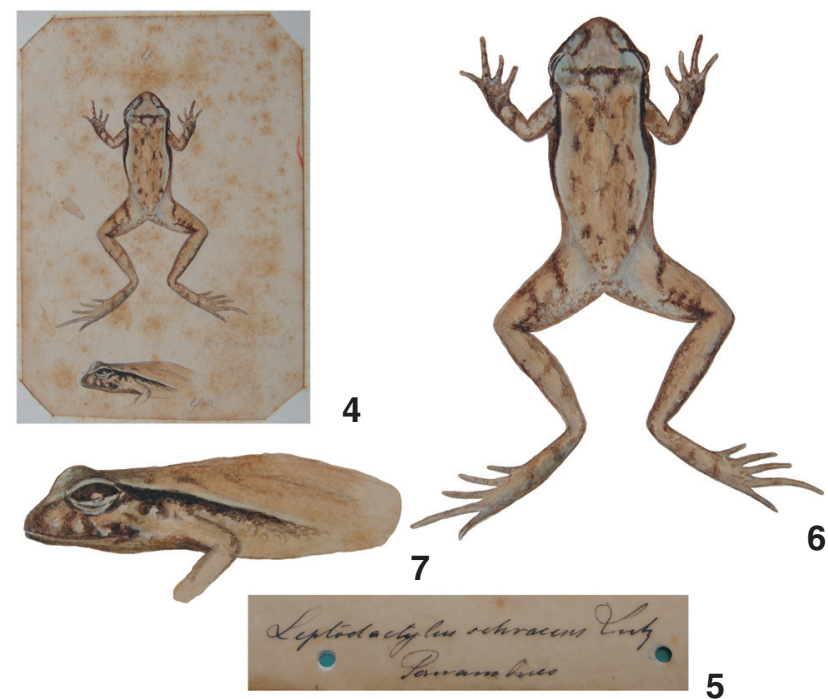

Figures 4-7. Leptodactylus ochraceus: (4) general view of the original plate ( $85 \times 122 \mathrm{~mm})$; (5) manuscript identification of the plate; (6) dorsal view; (7) lateral view.

4; END 4; ED 4 (in dorsal view), 5 (in lateral view); UEW 3; IOD 6; TD 3; THL 19; TL 21; FL 22.

Color: In the dorsal view, general color clear brown, slightly clearer laterally; canthus rostralis dark brown; interocular blotch approximately triangular with the apex directed forwards, laterally formed by dark brown bars and middle clear brown; elongated dark brown small blotches sparse on dorsum of body. Lateral dark brown bar visible from the eye to the middle of the flank. Forearms with two transverse dark brown bars; arms and hands pale to dark brown without bars. Left thigh with two and right thigh with one dark brown transverse bar; tibiae and feet with two transverse bars poorly defined.
The figure in lateral view shows the tip of the snout, the canthus rostralis, two subocular bars, and a not well-delimited stain on the corner of mouth, dark brown. A dark brown dorsolateral stripe from the posterior corner of eye, passing over the tympanum, and ending on the middle of the flank; the superior border of this lateral stripe is well delimited by a narrow clear brown, almost white, line; on the ventral portion, the dark brown lateral stripe vanishes and disappears towards the cream-colored belly.

The figures were published in color and reduced $2 / 3$ of the original size as "Fig. $4 \& 4 \mathrm{a}:-$ L. ochraceus n. sp." in Plate I of Lutz (1930) (Fig. 8).

\section{DISCUSSION}

Leptodactylus ochraceus cannot be associated to any of the former "hylid frogs" of South America, currently included into Amphignathodontidae, Cryptobatrachidae, Hemiphractidae, and Hylidae (sensu Frost et al. 2006). In reality, L. ochraceus undoubtedly belongs to Leptodactylidae based on all morphological traits.

In Northeastern Brazil, ten species of Leptodactylus (sensu Frost et al. 2006) have been recorded for the "Caatingas" domain (sensu Aв'SÁber 1977) according to ArZAbe et al. (2005), Borges-Nojosa \& Cascon (2005), Borges-Nojosa \& Santos (2005), and Rodrigues (2005): L. fuscus (Schneider, 1799), L. labyrinthicus (Spix, 1824) (currently L. vastus Lutz, 1930; see Heyer 2005), L. latinasus Jiménez de la Espada, 1875 (currently L. caatingae; see Heyer \& Juncá 2003), L. mystaceus (Spix, 1824), L. natalensis Lutz, 1930, L. ocellatus (Linnaeus, 1758) (or Leptodactylus gr. ocellatus), L. podicipinus (Cope, 1862), L. syphax Bokermann, 1978, L. troglodytes Lutz, 1926, and Leptodactylus sp. (cited as Adenomera sp.; Borges-Nojosa \& CAscon 2005). None of these species agree in morphology or in color with L. ochraceus. Additionally, the species of the other "leptodactylid" genus oc-

Revista Brasileira de Zoologia 25 (3): 523-528, September, 2008 


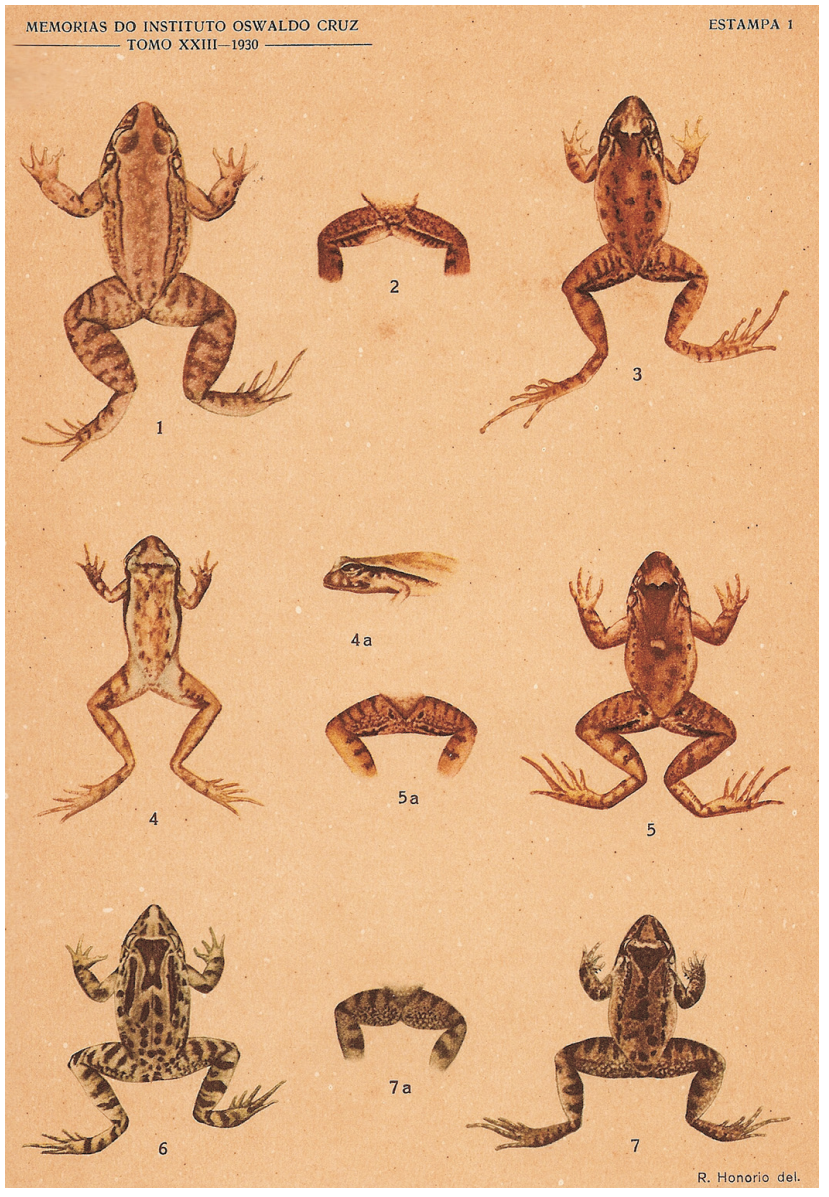

Figure 8. Published Plate I of Lutz (1930) showing "Fig. 4 \& 4a:-L. ochraceus n. sp."

curring in the region - Leiuperidae: Physalaemus albifrons (Spix, 1824), P. centralis Bokermann, 1962, P. cicada Bokermann, 1966, P. cuvieri Fitzinger, 1826 (or Physalaemus gr. cuvieri), P. gracilis (Boulenger, 1883) (this species actually does not occur in Northeastern Brazil and should be excluded from the list; see, NASCimento et al. 2005), and P. kroyeri (Reinhardt \& Lütken, 1862) (or Physalaemus cf. kroyeri), Pleurodema diplolister (Peters, 1870) (as P. diplolistris), Pseudopaludicola sp. 1 and Pseudopaludicola sp. 2 [treated as Pseudopaludicola falcipes (Hensel, 1867) and $P$. mystacalis (Cope, 1887) by Rodrigues 2005, but these species do not occur in Northeastern Brazil; see Frost 2007b]; Cycloramphidae: Proceratophrys cristiceps (Müller, 1884); and Ceratophryidae: Ceratophrys joazeirensis Mercadal de Barrio, 1986 (families sensu Frost et al. 2006) -, are also highly different and completely distinguishable from L. ochraceus.

Leptodactylus ochraceus is apparently a forgotten name, from its publication until the short reference made by BOKERMANN (1966). The name was not later mentioned in the catalogues of Gorham (1974), Harding (1983), and Frost (1985), nor in Duellman
(1993). It reappeared in the online version of the Frost's catalogue (2006, 2007a), but in the current version (2007b), the search under the name Leptodactylus ochraceus results that "there were no records returned for your query", and the name appears only as Incertae Sedis under Gastrotheca Fitzinger, 1843. The species was not analyzed and did not appear in the lists of threatened species of the Brazilian fauna (MACHADO et al. 2005), in the Global Amphibians Assessment (IUCN/CI/NS 2007), in the IUCN Red List (IUCN 2007), nor in the list of species of Brazilian amphibians (SBH 2007). However, Leptodactylus ochraceus Lutz, 1930 is a perfectly available name for a real species, currently represented only by its holotype.

At the time of collecting, in 1927, the type locality of $L$. ochraceus, Tapera (currently Bonança), in the State of Pernambuco, Northeastern Brazil, was a poorly inhabited and well preserved region. Currently, after 80 years of human activities and occupation, the same region is severely altered and it is possible that the habitat of the species longer exists. On March 31, 2008 , attempts to collect L. ochraceus in the region of the type locality were unsuccessful. However, before considering the species extinct or to include it in any of the threatened-species categories, it will be necessary to prospect the original locality and adjacent more preserved areas.

\section{ACKNOWLEDGEMENTS}

I thank Carlos Alberto G. Cruz and Marinus S. Hoogmoed, for critically reading the manuscript; Dante M. Teixeira, for help with the proper localization of the type locality; Carlos Alberto G. Cruz and Bruno V.S. Pimenta, for the pleasant companionship in the fieldwork. I also thank the Conselho Nacional de Desenvolvimento Científico e Tecnológico, for the PQ 1A fellowship and grant.

\section{LITERATURE CITED}

Aв'Sáber, A.N. 1977. Os domínios morfoclimáticos na América do Sul. Primeira aproximação. Geomorfologia 52: 1-21.

Arzabe, C.; G. Skuk; G.G. Santana; F.R. Delfim; Y.C.C. Lima \& S.H.F. Abrantes. 2005. Herpetofauna da área de Curimataú, p. 259273. In: F.S. Araújo; M.J.N. Rodal \& M.R.V. Barbosa (Eds). Análise das variações da biodiversidade do bioma Caatinga. Suporte a estratégias regionais de conservação. Brasília, Ministério do Meio Ambiente, Secretaria de Biodiversidade e Florestas, 446p.

BoKERMANN, W.C.A. 1966. Lista anotada das localidades tipo de anfíbios brasileiros. São Paulo, Serviço de Documentação, Reitoria da Universidade de São Paulo, 183p.

Borges-Nojosa, D.M. \& P. Cascon. 2005. Herpetofauna da área Reserva da Serra das Almas, Ceará, p. 243-258. In: F.S. ARAúJo,; M.J.N. Rodal \& M.R.V. Barbosa (Eds). Análise das variações da biodiversidade do bioma Caatinga. Suporte a estratégias regionais de conservação. Brasília, Ministério do Meio Ambiente, Secretaria de Biodiversidade e Florestas, 446p. 
Borges-Nojosa, D.M. \& E.M. Santos. 2005. Herpetofauna da área de Betânia e Floresta, Pernambuco, p. 275-289. In: F.S. ARAúJo, M.J.N. Rodal \& M.R.V. Barbosa (Eds). Análise das variações da biodiversidade do bioma Caatinga. Suporte a estratégias regionais de conservação. Brasília, Ministério do Meio Ambiente, Secretaria de Biodiversidade e Florestas, 446p.

Duellman, W.E. 1993. Amphibian species of the world: additions and corrections. Museum of Natural History of the University of Kansas Special Publications (21): 1-372.

Frost, D.R. 1985. Amphibian species of the world. A taxonomic and geographical reference. Lawrence, Allen Press, The Association of Systematics Collections, V+732p.

Frost, D.R. 2006. Amphibian species of the world: an online reference. New York, American Museum of Natural History, version 4, 17.VIII.2006, electronic database available online at: http://research.amnh.org/herpetology/amphibia/ index.php. [Accessed: 27.X.2006].

Frost, D.R. 2007a. Amphibian dpecies of the world: an online reference. New York, American Museum of Natural History, version 5.0, 1.II..2007, electronic database available online at: http://research.amnh.org/herpetology/amphibia/ index.php[Accessed: 01.VI.2007].

Frost, D.R. 2007b. Amphibian species of the world: an online reference. New York, American Museum of Natural History, version 5.1, 10.X.2007, electronic database available online at: http://research.amnh.org/herpetology/amphibia/ index.php[Accessed: 25.XI.2007].

Frost, D.R.; T. Grant; J. Faivovich; R.H. Bain; A. Haas; C.F.B. Haddad; R.O. De Sá; A. Channing; M. Wilkinson; S.C. Donellan; C.J. Raxworthy; J.A. Campbell; B.L. Blotto; P. Moler; R.C. Drewes; R.A. Nussbaum; J.D. Lynch; D.M. Green \& W.C. Wheeler. 2006.The amphibian tree of life. Bulletin of the American Museum of Natural History (297): 1-370.

Gorham, S.W. 1974. Checklist of world amphibians up to January 1, 1970. Saint John, Lingley Printing , 173p.

Harding, K.A. 1983. Catalogue of New World Amphibians. Oxford, Pergamon Press, XVI+406p.

HeYer, W.R. 2005. Variation and taxonomic clarification of the large species of the Leptodactylus pentadactylus species group (Amphibia: Leptodactylidae) from Middle America, Northern South America, and Amazonia. Arquivos de Zoologia 37 (3): 269-348.
Heyer, W.R. \& F.A. Juncá. 2003. Leptodactylus caatingae, a new species of frog from eastern Brazil (Amphibia: Anura: Leptodactylidae). Proceedings of the Biological Society of Washington 116 (2): 317-329.

Heyer, W.R.; A.S. Rand; C.A.G. Cruz; O.L. Peixoto \& C.E. Nelson. 1990. Frogs of Boracéia. Arquivos de Zoologia 31 (4): 231410.

IUCN. 2007. 2007 The World Conservation Union red list of threatened species. Electronic database available online at: http://www.iucnredlist.org [Accessed in 26.XI.2007].

IucN/CI/Ns . 2007. Global Amphibian Assessment. The World Conservation Union, Conservation International, Nature Serve, electronic database available online at: http://www. globalamphibians.org [Accessed: 26.XI.2007].

LuTz, A. 1926. Observações sobre batrachios brasileiros. Parte I: O gênero Leptodactylus Fitzinger. Observations on brazilian batrachians. Part I: The genus Leptodactylus. Memórias do Instituto Oswaldo Cruz 19 (2): 139-174.

LuTz, A. 1930. Segunda memoria sobre especies brasileiras do genero Leptodactylus, incluindo outras alliadas. Memórias do Instituto Oswaldo Cruz 23 (1): 1-34, 5pls.

Machado, A.B.M.; C.S. Martins \& G.M. Drummond (Eds.) 2005. Lista da fauna brasileira ameaçada de extinção. Incluindo as listas das espécies quase ameaçadas e deficientes de dados. Belo Horizonte, Fundação Biodiversitas, 160p.

Nascimento, L.B.; U. Caramaschi \& C.A.G. Cruz. 2005. Taxonomic review of the species groups of the genus Physalaemus Fitzinger, 1826 with revalidation of the genera Engystomops Jiménez-de-la-Espada, 1872 and Eupemphix Steindachner, 1863 (Amphibia, Anura, Leptodactylidae). Arquivos do Museu Nacional 63 (2): 297-320.

Rodrigues, M.T. 2005. Herpetofauna da caatinga, p. 181-236. In: I.R.Leal; M. TABARELLI \& J.M.C. Silva (Eds). Ecologia e conservação da Caatinga. Recife, Editora Universitária da UFPE, $2^{\mathrm{a}}$ ed., 822p.

SвH. 2007. Brazilian amphibians - list of species. Sociedade Brasileira de Herpetologia, electronic database avalaible online at: http://www.sbherpetologia.org.br. [Accessed: 26.XI.2007].

Submitted: 29.II.2008; Accepted: 08.IX.2008.

Editorial responsibility: Ana Lúcia da Costa Prudente

Appendix. Examined specimens.

Gastrotheca fissipes: BrAsIL, Bahia: Alcobaça (MNRJ 19332); Una, Ecoparque de Una (MNRJ 27235). Espírito Santo: Linhares, Sooretama (MNRJ 4061).

Leptodactylus caatingae: Brasil, Paraíba: São João do Cariri (MNRJ 10825-10827). Bahia: Barra (MNRJ 38307-38308).

Leptodactylus fuscus: Brasil, Rio Grande do Norte: Lagoa Nova (MNRJ 38635-38636). Sergipe: Cristinápolis (MNRJ 47137); Indiroba (MNRJ 46743-46745). Bahia: Alcobaça (MNRJ 47824); Boa Nova (MNRJ 46516); Valença (MNRJ 30562-30570).

Leptodactylus mystaceus: BrasiL, Pará: Belém (MNRJ 1470). Pernambuco: Igarassú (MNRJ 2363). Goiás: Jatobazinho, Aliança (MNRJ 2699, 12393-12396). Minas Gerais: João Pinheiro (MNRJ 38820). 
Leptodactylus natalensis: BRASIL, Ceará: Guaramiranga (MNRJ 27535-27536). Pernambuco: Bodocó (MNRJ 44059-44060). Alagoas: Coruripe (MNRJ 38138-38139); Murici (MNRJ 9718); São Miguel dos Campos (MNRJ 9591, 36733). Sergipe: Cristinápolis (MNRJ 32865). Bahia: Esplanada (MNRJ 32570-32576); Ilhéus (MNRJ 4982-4987); Itamaraju (MNRJ 29796-29799).

Leptodactylus podicipinus: Brasil, Pará: Alter do Chão (MNRJ 32527-32529). Maranhão: Balsas (MNRJ 44722). Goiás: Aporé (MNRJ 41358-41361); Pontalina (MNRJ 32414-31422). Minas Gerais: João Pinheiro (MNRJ 38823-38824); Pirapora (MNRJ 1047, 47178).

Leptodactylus syphax: Brasil, Goiás: UHE Serra da Mesa (MNRJ 20187-20202). Minas Gerais: Santana do Riacho, Serra do Cipó (MNRJ 38739, 39025); Unaí, AHE Queimado (MNRJ 35558, 35564).

Leptodactylus troglodytes: BrasiL, Ceará: Barro (MNRJ 32932); Brejo Santo (MNRJ 35926, 40359-40372). Pernambuco: Caruaru (MNRJ 38658). Alagoas: São Miguel dos Campos (MNRJ 9528). Sergipe: Estância (MNRJ 37915-37916); Indiroba (MNRJ 46733-46734). Bahia: Caetité (MNRJ 43915-43916); Valença (MNRJ 35918-35922).

Leptodactylus vastus: BRASIL, Ceará: Miranda (MNRJ 2550). Pernambuco: Bodocó (MNRJ 30945); Recife (MNRJ 3209). Alagoas: Murici (MNRJ 9767); São Miguel dos Campos (MNRJ 9688). Bahia: Caetité (MNRJ 27191).

Leptodactylus gr. ocellatus: Brasil, Ceará: Caucaia (MNRJ 42936). Alagoas: Passo do Camaragibe (MNRJ 9890-9892); São Miguel dos Campos (MNRJ 9651-9656). Bahia: Caetité (MNRJ 25041-25045); Ibirapitanga (MNRJ 29604); Ilha de Itaparica (MNRJ 4219342194); Ilhéus (MNRJ 29969-29971).

Leptodactylus sp. (= Adenomera sp.): Brasil, Paraíba: Areia (MNRJ 19073-19075). Alagoas: Coruripe (MNRJ 38152); Murici (MNRJ 9471). Bahia: Boa Nova (MNRJ 46474).

Physalaemus albifrons: Brasil, Maranhão: Barreirinha (MNRJ 24216-24226). Ceará: Brejo Santo (MNRJ 24062-24072); Fortaleza (MNRJ 1125, 6636-6676). Sergipe: Santa Luzia do Itanhy (MNRJ 17976-17981). Bahia: Barreiras (MNRJ 1094-1096); Bom Jesus da Lapa (MNRJ 1089-1091, 1094-1096, 1102-1104); Juazeiro (MNRJ 1105).

Physalaemus centralis: Brasil, Goiás: Silvânia (MNRJ 17425). Mato Grosso: Xingu, Rio Coluene (MNRJ 14220-14221). Minas Gerais: Manga (MNRJ 26844); Pirapora (MNRJ 25487-25501); Várzea da Palma (MNRJ 27176-27178).

Physalaemus cicada: Brasil, Ceará: Brejo Santo (MNRJ 24060, 28552-28553). Minas Gerais: Matias Cardoso (MNRJ 21750-21752).

Physalaemus cuvieri: Brasil, Maranhão: São Pedro das Águas Brancas (MNRJ 24255-24266). Goiás: Minaçu, UHE Serra da Mesa (MNRJ 20268-20282); São João da Aliança (MNRJ 27762-27762). Minas Gerais: Belmiro Braga (MNRJ 27554-27555); São Gonçalo do Rio Abaixo, Peti (MNRJ 24881-24897).

Physalaemus kroyeri: Brasil, Bahia: Boa Nova (MNRJ 46489, 46493-46464). Minas Gerais: Novo Cruzeiro (MNRJ 35130-35135).

Pleurodema diplolister: Brasil, Piauí: Brejo do Piauí (MNRJ 44735-44737), Parnaíba (MNRJ 49863-49870); Picos (MNRJ 5038150382). Ceará: Brejo Santo (MNRJ 50383-50385); Mucuripe (MNRJ 2586, 11489-12007). Pernambuco: Caruaru (MNRJ 38659); Casinha (MNRJ 470); Dormentes (MNRJ 30005); Ouricuri (MNRJ 30021). Alagoas: Feliz Deserto (MNRJ 9946-9958); Sergipe: Brejo Grande (MNRJ 38121-38127, 43747-43766). Bahia: Bom Jesus da Lapa (MNRJ 1734, 2502, 11380-11387); Juazeiro (MNRJ 2580, 11727-11820); Valença (MNRJ 32867-32868).

Pseudopaludicola sp.: BrasiL, Piauí: Brejo do Piauí (MNRJ 44723-44726); Parnaíba (MNRJ 49942-49944); Piripiri (MNRJ 36622); Uruçui (MNRJ 39776-39782). Ceará: Barro (MNRJ 34330-34355); Caucaia (MNRJ 42937-42940); Fortaleza (MNRJ 981-983); Mucuripe (MNRJ 984, 997, 6401-6455, 6512-6525). Rio Grande do Norte: Mossoró (MNRJ 38700-38712). Pernambuco: Bodocó (MNRJ 40769-40778); Exu (MNRJ 30019-30020); Jaboatão (MNRJ 611, 7068-7069); Recife (MNRJ 948, 6179-6189). Alagoas: Coruripe (MNRJ 38153-38156); Feliz Deserto (MNRJ 9936-9944); Passo do Camaragibe (MNRJ 9814-9815, 10588-10561, 42382); São Miguel dos Campos (MNRJ 9530-9537, 36685-36695). Sergipe: Itaporanga d'Ajuda (MNRJ 46770-46784); Santa Luzia do Itanhy (MNRJ 17935-17943); São Cristóvão (MNRJ 17994-17003). Bahia: Barreiras (MNRJ 991, 6491-6511); Bom Jesus da Lapa (MNRJ 980, 1002); Conde (MNRJ 47563-47587); Juazeiro (MNRJ 1003-1004); Maracás (MNRJ 21014-21086, 43325); Rio Grande (MNRJ 965, 973, 998-1000, 6372-6377); Valença (MNRJ37091-37094, 44074).

Proceratophrys cristiceps: BRASIL, Ceará: Mucuripe (MNRJ 1419-1420, 1680, 16470-16600). Pernambuco: Timbaúba (MNRJ 50379). Paraíba: Areia (MNRJ 50378). Sergipe: Brejo Grande (MNRJ 50376); São Cristóvão (MNRJ 50377). Bahia: Barreiras (MNRJ 1737); Feira de Santana (MNRJ 47839).

Ceratophrys joazeirensis: BrasiL, Pernambuco: Timbaúba (MNRJ 50380). 